NBER WORKING PAPER SERIES

NEW EVIDENCE ON THE EFFECTS OF EXCHANGE RATE INTERVENTION

Martin Feldstein

Working Paper No. 2052

NATIONAL BUREAU OF ECONOMIC RESEARCH

1050 Massachusetts Avenue

Cambridge, MA 02138

October 1986

The research reported here is part of the NBER's research program in International Studies. Any opinions expressed are those of the author and not those of the National Bureau of Economic Research. 
NBER Working Paper \#2052

October 1986

New Evidence on the Effects of Exchange Rate Intervention

\section{ABSTRACT}

The September 1985 decision of the G-5 countries to pursue coordinated intervention has been widely credited with the subsequent sharp decline of the dollar relative to other major currencies. On the surface, the dollar's decline appears as evidence that coordinated intervention can be an effective instrument of economic policy, contrary to most of the previous economic analysis of this issue.

The evidence in the present paper shows that such a conclusion is unwarranted. The dollar's decline in the nine months after the G-5 agreement was generally no faster than it had been since the beginning of its decline in the spring of 1985. The only indication of discontinuity in the overall behavior of the dollar was a drop of about 4 percent that occurred immediately after the G-5 meeting and that has largely persisted.

Although this evidence cannot be taken as a conclusive indication that coordinated intervention had no effect on the dollar's rate of decline, it does show the inappropriateness of interpreting the dollar's decline after september 1985 as evidence that coordinated intervention was effective.

The special case of the Japanese yen is more ambiguous. Unlike all of the other G-5 currencles, the yen did appreciate more rapidly after the G-5 meeting than it did before. But the Japanese government was also unique in making a major shift in monetary policy immediately after the G-5 meeting to strengthen the yen and the yen was also the major currency that could be expected to appreciate most as a result of the massive and unexpected decline of the price of oil in the first half of 1986. 


\title{
New Evidence on the Effects of Exchange Rate Intervention
}

\author{
Martin Feldstein*
}

The sharp rise in the value of the dollar that began in 1980 eventually brought widespread calls for active government intervention in foreign exchange markets. American business leaders wanted the dollar reduced because they recognized that the strong dollar was depressing exports and encouraging a major increase in imports to the United states. More surprisingly. European officials wanted to see a lower dollar because the rising dollar created inflationary pressure in their own countries that was inducing them to pursue an undesirably tight monetary policy. ${ }^{2}$ while the Japanese government favored a lower dollar to ease the protectionist sentiment developing in the United states.

Most economists, even if they accepted the desirability of lowering the dollar's value, rejected pure exchange market intervention as an ineffective policy instrument. Since the

* Professor of Economics, Harvard University, and President, The National Bureau of Economic Research. I am grateful to Fiona Scott-Morton for help with the calculations reported in this paper and to Data Resources. Inc. for the use of computing facilities. This research is part of the NBER Research Project on Exchange Rate Misalignment.

1 See Feldstein (1986a) and Feldstein and Bacchetta (1986) for a discussion of the effect of the strong dollar on European monetary and fiscal policy. 
exchange value of the dollar is determined by the interaction of supply and demand in world security markets, the magnitude of intervention is inevitably too small to have a significant and sustained effect on the dollar exchange rate. ${ }^{2}$ Although the dollar's value could be reduced by a nonsterilized intervention in which the U.S. government increased the U.S. money supply by the same volume of dollars that it exchanged for foreign currencies, the real reason for the dollar's fall in such a case would be the easing of U.S. monetary policy and not the intervention in foreign exchange markets.

This view was well summarized by Obstfeld (1985, p. 395) when he wrote: "... the overwhelming conclusion of recent research is that in the present international environment, only intervention that is permitted to affect the money supply has a significant impact on the exchange rate." An international group of experts appointed by the International Monetary Fund stated a similar if more guarded conclusion in its 1983 report to the IMF Interim Committee (The Jurgensen Report of the Working Group on Exchange Market Intervention).

But although widely held, this view of the ineffectiveness of sterilized intervention is far from the unanimous judgement of respected international economists. Those who believe that sterilized intervention can be effective emphasize that price setting in exchange rate markets is dominated by changes in

\footnotetext{
3 The daily volume of foreign exchange trading in London. New York and Tokyo as of March 1986 was officially estimated to be $\$ 188$ billion.
} 
expectations and risk premia rather than by shifts in the current stocks of financial assets. The prospect of government intervention, especially the coordinated intervention of several leading governments, can change the expectations or at least the perceived risks of holding individual currencies. This is particularly true when a government is thought to be committed to reducing rather than defending the value of its own currency since it has an effectively unlimited supply of the currency for that purpose.

Thus Richard Cooper (1985, p. 454) explicitly rejected Obstfeld's conclusion, writing that "The evidence is, in fact. guite ambiguous: the tests are weak: they apply mainly to the influence of asset composition on the exchange risk premium rather than to sterilized intervention as such: and they often assume rational expectations, which may be what the tests are really rejecting." Similarly, Fred Bergsten (1986, p. 233) advocated that "the major central banks should take advantage of just such occasions - when the markets are already pushing currency relationships in the direction of underlying equilibrium - through joint intervention to promote the needed degree of adjustment. Such 'leaning with the wind' would have important signalling as well as substantive effects..." Even the Jurgensen Report held out the possibility that coordinated intervention might be more powerful that the sum of the individual interventions because of its psychological impact and that there might be a synergistic interaction if coordinated intervention 
were pursued in conjunction with other macroeconomic policies.3 Resistance by the U.S. government precluded any coordinated intervention against the dollar until september 1985. Economists in the Reagan administration generally believed that nonsterilized intervention would be ineffective in itself and likely to evolve into a sterilized intervention that caused an unwarranted inflationary easing of money. Some administration political officials pointed to the strong dollar as evidence of the world's approval of American economic policies and attributed much of the increased trade deficit to rapid U.S. growth and foreign protectionism rather than the level of the dollar.

But by september 1985, the magnitude of the U.S. trade deficit, the increasing Congressional threat of protectionist legislation, and the changes in senior administration economic officials produced a new attitude toward intervention in the Reagan administration. In addition, the dollar's decline since March of that year meant that political spokesmen could no longer point to the rising dollar as an indication of the world's approbation of Reaganomics.

The meeting of the finance ministers and central bank leaders of the G-5 countries (the U.S.. Germany, Japan. England and France) at the Plaza Hotel in New York on September 22, 1985 brought an abrupt change in U.S. policy and began a period of

3 Although Ronald McKinnon was a forceful advocate of intervention to reduce the dollar's value, he argued for nonsterilized intervention because he believed that the high value of the dollar reflected an excessively tight monetary policy. See, e.g.. Mckinnon (1983). 
coordinated exchange rate intervention. At the end of the meeting, U.S. Treasury Secretary James Baker reversed the prevailing position of the Reagan administration by announcing that the dollar was overvalued and that the American economy would benefit from a decline of the dollar. Secretary Baker then went substantially further in reversing the position of the American government by agreeing with the other G-5 finance ministers that the United states would join with other countries in coordinated intervention in foreign exchange markets. The central banks of the major countries intervened heavily in the days after the release of the G-5 communique.

The dollar fell immediately, declining about 5 percent against major currencies in the first day of trading after the G-5 meeting. In the following nine months, the dollar slid an additional 25 percent against the yen, 18 percent against the German mark, and 15 percent against a multilateral trade weighed basket of currencies.

Throughout this period, the G-5 meeting and the willingness of the major governments to engage in coordinated intervention has been hailed in the popular press and in official circles as the cause for the dollar's sharp decline. In contrast, academic researchers have been surprisingly quiet about the implications of the G-5 experiment for the previous debate about the effectiveness of exchange market intervention. The purpose of the present paper is to see whether the traditional skepticism about the efficacy of sterilized intervention needs to be 
reconsidered in light of the experience of the past year.

There have of course been many events during the year beginning in september 1985 that taken together could, in principle, explain the dollar's decline. * Japan first tightened and then eased domestic monetary policy. The growth rate of the United States waned. The Federal Reserve reduced the discount rate several times and allowed $M 1$ to surge above the upper limit of its target range. The price of oil collapsed to less than half of its value at the beginning of the period. In short, there were more than enough important changes in the economic situation so that those who wished to hold to the view that intervention and the prospect of intervention are ineffective need not change their minds despite the dollar's sharp decline of the past year.

But the case that the G-5 agreement and the subsequent coordinated exchange market intervention have not altered the pace of the evolution of the dollar is much stronger than this appeal to an abundance of other possible explanations of the dollar's rapid decline. The evidence presented in this paper indicates that the decline in the dollar after the G-5 meeting was essentially just a continuation of the decline that had begun

- I say "in principle" because the experience with econometric models of short-run exchange rate movements has not been very satisfactory. See, for example, the analysis in Meese and Rogoff (1985). Of course, these models may simply have misspecified the process of exchange rate determination. For evidence of the ability to explain longer-term movements of the dollar in terms of economic fundamentals, see Feldstein (1986b) and the works cited therein. 
six months earlier. There has been no significant and sustained acceleration in the pace of the dollar's decline to be attributed to coordinated intervention or to the new attitude of the U.S. government.

More specifically, the overall trade-weighted value of the dollar dropped by 3.1 percent immediately after the G-5 meeting but then continued to decline at the same average rate of 2.0 percent a month rate for the next nine months that it had experienced since the decline began in March 1985. The statistical evidence for the German mark and the Swiss franc are quite similar. Among the G-5 currencies, only the Japanese yen showed a significantly more rapid decline in the months after the G-5 meeting than it had before: some possible reasons for this difference are discussed below.

of course, the evidence that the dollar has been declining at the same pace against the trade-weighted basket of other currencies since the G-5 meeting that it was before is not proof that the G-5 rhetoric and subsequent coordinated intervention have not been influential. Defenders of the efficacy of intervention can claim that other factors have offset the acceleration of the dollar's decline that the intervention would otherwise have produced. Or, more simply, they might argue that without intervention the previous decline of the dollar would have slowed or stopped. These possibilities cannot be resolved until a convincing econometric model of exchange rate determination that covers this period has been estimated. But 
the evidence in this paper eliminates the apparent prima facie case that the shift in exchange rate intervention policy has produced a sharp decline of the dollar.

The paper begins by examining the monthly behavior of a trade-weighted index of the value of the dollar and then, in section 2, considers five other measures of the dollar's movement: the bilateral exchange rate index calculated by the Morgan Guaranty Bank and the exchange rates between the dollar and the German mark, the Swiss franc, the British pound, and the Japanese yen. The third section briefly analyzes corresponding behavior with weekly data. There is a final concluding section.

\section{Tests of Discontinuity of the Dollar's Decline}

Figure 1 shows the Federal Reserve Board's multilateral trade-weighted index of the value of the dollar in each month between January 1985 and June 1986, the latest complete month at the time that the present study began.5 This series is defined as a weighted average of the dollar exchange rates for the other G-11 countries, welghting by their shares in global trade in 1972 through 1976. The vertical line through september 1985 indicates the time of the G-5 Plaza meeting.

The dollar, which had been rising since the middle of 1980 . reached a peak in February 1985 and then began to decline. A

5 I am grateful to the Board of Governors of the Federal Reserve system for providing these data. This series corresponds to the multilateral trade weighted dollar value published annually in the Economic Report of the President. 
Figure 2

The Multilateral Trade Weighted Value of the Dollar

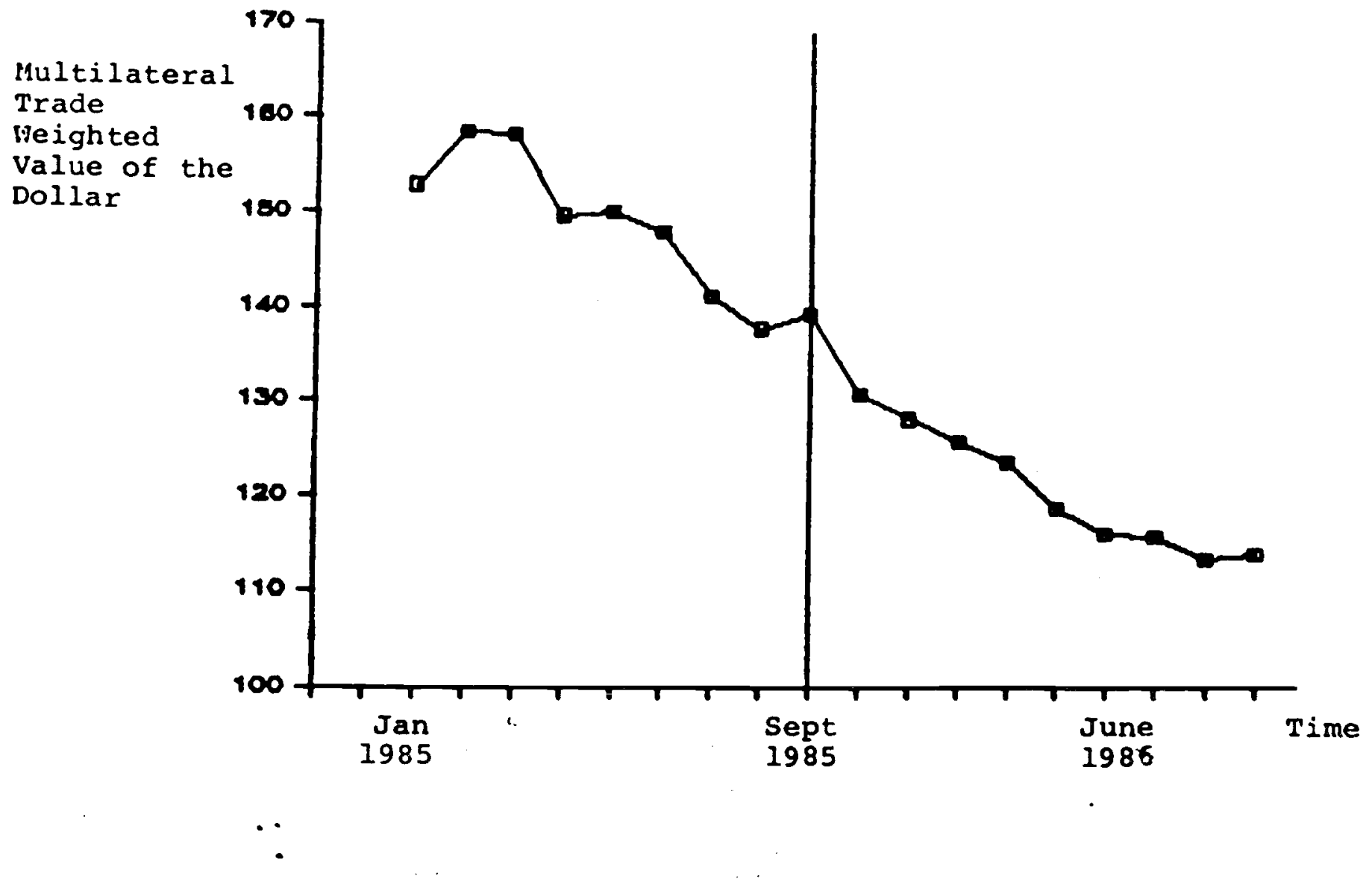


least squares regression of the logarithm of the dollar exchange rate index on a time trend shows a decline at a rate of 2.3 percent a month from March 1985 through June 1986:

(1) In DOLMTW = $5.094-\underset{(0.001)}{-0.023 \mathrm{Time}}$ $1985: 3-1986: 6$ $R^{2}=0.98$ DWS $=1.8$

where DOLMTw is the multilateral trade weighted index of the dollar value and time is a linear time trend in which the unit is one month.

To test whether the dollar declined more rapidly after the G-5 meeting, a second time trend (Time2) is added which takes the value zero until september 1985 and then increases at one unit per month from October 1985 through June 1986:

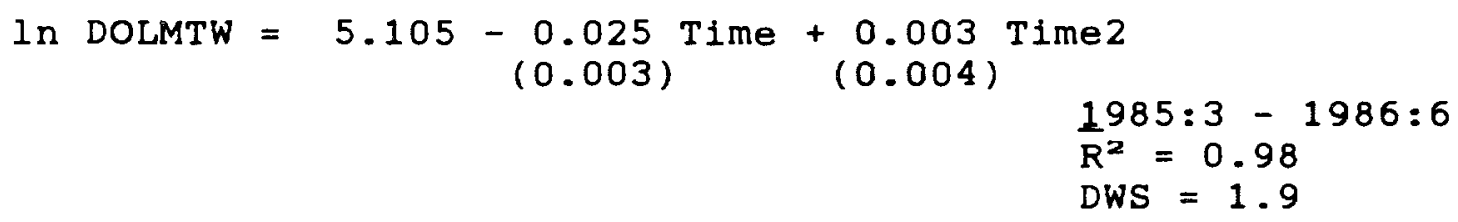

The point estimate of the coefficient of the Time2 variable implies that the dollar actually fell more slowly in the period since the G-5 meeting than in the months before. But the coefficient is less than its standard error and therefore cannot be regarded as significantly different from zero.

A more general test of a discontinuity in the trend of the dollar's value is provided by equation 3 that adds a shift term 
equal to zero through september 1985 and then equal to one thereafter:

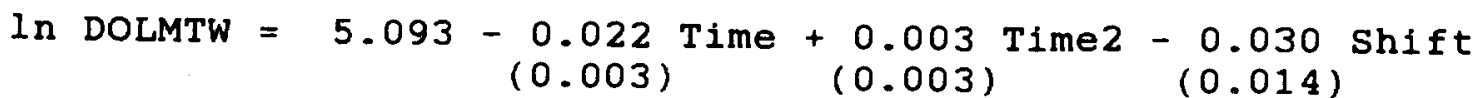

$$
\begin{aligned}
& 1985: 3-1986: 6 \\
& R^{2}=0.98 \\
& \text { DWS }=2.0
\end{aligned}
$$

Although the coefficient of the second time trend variable (Time2) remains very small and not significantly different from zero, the coefficient of the shift variable implies that, after adjusting for the time trend, the value of the dollar was three percent lower in the period after the G-5 meeting than it had been during the previous months. Since the immediate effect of the G-5 meeting was a drop of approximately five percent in the dollar relative to this multilateral index, the shift parameter indicates that this one-time decline was partially preserved during the subsequent months.

since the second time trend remains insignificant in this specification, the basic relation with a single time trend and the shift parameter is re-estimated as equation 4:

\footnotetext{
(4) In DOLMTW $=5.084-0.020$ Time -0.031 Shift $(0.002) \quad(0.014)$

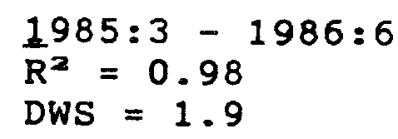


Equation 4 indicates a 2.0 percent per month rate of decline over the entire period with an additional one-time 3 percent decline after the G-5 meeting. The magnitude of this downward shift is thus approximately equal to the trend decline that occurs in six weeks. One possible interpretation of this shift is that the prospect of exchange market intervention created a persistent risk differential that lowered the dollar by three percent. One source of ambiguity in defining these tests is the proper treatment of september 1985, the month in which the G-5 meeting occurred. I have therefore re-estimated all of the equations with a sample that excludes september 1985. The results are quite similar to the equations that have been presented although omitting september reduces the size and statistical significance of the shift effect. Thus, analogous to equation 3 but for the modified sample, the estimates are:

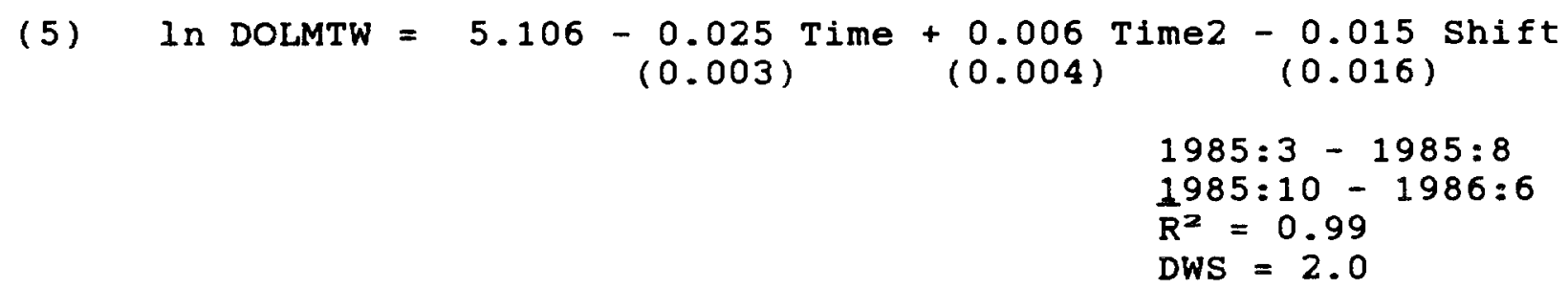

The point estimates indicate that the time trend is slightly stronger before september $(2.5$ percent a month instead of the 2.2 percent estimated in equation 3) but the same after the G-5 meeting ( 1.9 percent a month). The large standard errors. however, suggest that this is probably just random variation and 
that there was no change in the trend rate of decline of the dollar. The shift coefficient is only half of its value in equation 3 and less than its standard error.

Omitting the Time2 variable (i.e.. estimating a specification similar to equation 4) still leaves the coefficient of the Shift variable insignificant ( 0.024 with a standard error of 0.016). A statistically superior specification in this sample is the analog of equation 2:

(6) In DOLMTW $=5.114-\underset{(0.002)}{-0.028}$ Time $+\underset{(0.003)}{(0.007}$ Time2

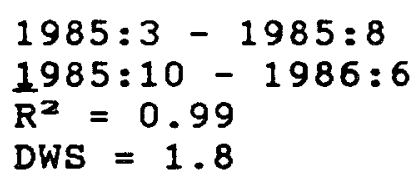

This specification implies that the rate of decline of the dollar fell by about one fourth after the G-5 meeting and that there was no persistent downward shift in the level of the dollar. Although I would not argue that it is better to omit the September observation in this way, I would note that dealing with the sample problem in this way reinforces the conclusion that G-5 meeting did not initiate a decline in the value of the dollar.

A second type of specification ambiguity is the choice between a logarithmic and a linear specification. While the proportional rate of change implied by the logarithmic specification seems most natural in the current context. the alternative linear specification was also estimated. The results 
are very similar to the logarithmic specification. For example, when all months are included in the sample, the second time trend variable is actually positive in the specifications analogous to equations 2 and 3 . The shift coefficient is however negative. more than twice its standard error, and approximately one and a half times the monthly decline. Omitting september changes the linear results in essentially the same way as the logarithmic specification. The shift coefficient is statistically insignificant while the second time trend is significantly positive.

These estimates of the behavior of the most general multilateral trade weighted measure of the dollar exchange rate provide no support for the view that the dollar declined more rapidly after the G-5 meeting than it did before. Any persistence of the downward shift that occurred immediately after the G-5 meeting is ambiguous and depends on whether the sample is defined to include or exclude the month of the G-5 meeting.

\section{Experience with Bilateral Exchange Rates}

Table 1 summarizes the estimated coefficients for equations similar to 1 through 4 for bilateral exchange rates between the dollar and the German mark, the Swiss franc, the English pound and the Japanese yen as well for the frequently cited Morgan Guaranty Bank bilateral weighted index of the dollar's value. For comparison, the multilateral trade weighted estimates of equations 1 through 4 are also presented. Separate estimates are 
given for logarithmic and for linear time trends. All of the estimates are based on the entire sample of monthly observations from March 1985 through June 1986.

The coefficients are presented in a way that is designed to give all of the relevant information in the minimum possible amount of space. Instead of presenting standard errors of the coefficients, a system of parentheses and square brackets is used to indicate the statistical significance of the coefficients. A coefficient that is presented without any parentheses or square brackets is more than twice its standard error; this is always true of the basic time trend. A coefficient in parentheses is more than its standard error but less than twice its standard error. Finally, a coefficient in square brackets is less than its standard error and therefore not significantly different from zero at even the 35 percent level. Constant terms are not shown because they are of no interest in the current context. Finally. since the corrected $R^{2}$ values generally exceed 0.9 and are not of interest per se, the value of this measure of fit is not shown; I comment below on the one case in which the correct $R^{2}$ value is less than 0.9 .

The first four rows under the logarithmic specification summarlze the coefficients for the multilateral trade weighted index already presented in equations 1 through 4 . The corresponding linear specifications are presented in the right hand half of the table. These have already been discussed and noed no further comment. 
Table 1

Analysis of Monthly Dollar Buchange Rate Kovenents

Barch 1985 through June 1986

\begin{tabular}{|c|c|c|c|c|c|c|c|c|}
\hline $\begin{array}{l}\text { Currency or } \\
\text { Inder }\end{array}$ & & $\begin{array}{l}\text { Logat: } \\
\text { Specif: }\end{array}$ & $\begin{array}{l}\text { thaic } \\
\text { cation }\end{array}$ & & & $\begin{array}{r}\text { Line } \\
\text { Specift }\end{array}$ & $\begin{array}{l}\text { ear } \\
\text { tcation }\end{array}$ & \\
\hline & Tive & Tise? & Shift & DHS & Hise & ILe? & Shift & Dis \\
\hline $\begin{array}{l}\text { Multilateral } \\
\text { Trade Meighted } \\
\text { Index }\end{array}$ & $\begin{array}{l}-.023 \\
-.025 \\
-.022 \\
-.020\end{array}$ & $\begin{array}{l}{[.003]} \\
{[.003]}\end{array}$ & $\begin{array}{l}-. \\
-.030 \\
-.031\end{array}$ & $\begin{array}{l}1.8 \\
1.9 \\
2.0 \\
1.9\end{array}$ & $\begin{array}{l}-.030 \\
-.037 \\
-.032 \\
-.026\end{array}$ & $\begin{array}{l}(.010) \\
(.009)\end{array}$ & $\begin{array}{l}-.042 \\
-.046\end{array}$ & $\begin{array}{l}1.5 \\
2.0 \\
2.0 \\
1.6\end{array}$ \\
\hline $\begin{array}{l}\text { Morgan Bank } \\
\text { Bilateral } \\
\text { Index }\end{array}$ & $\begin{array}{l}-.018 \\
-.018 \\
-.015 \\
-.015\end{array}$ & $\begin{array}{l}{[.000]} \\
{[.000]}\end{array}$ & $\begin{array}{l}-.021 \\
-.021\end{array}$ & $\begin{array}{l}2.3 \\
2.3 \\
2.2 \\
2.2\end{array}$ & $\begin{array}{l}-.021 \\
-.023 \\
-.020 \\
-.018\end{array}$ & $\begin{array}{l}{[.003]} \\
{[.003]}\end{array}$ & $\begin{array}{l}-.027 \\
-.028\end{array}$ & $\begin{array}{l}2.1 \\
2.3 \\
2.3 \\
2.1\end{array}$ \\
\hline $\begin{array}{l}\text { Gerean } \\
\text { Mart }\end{array}$ & $\begin{array}{l}-.027 \\
-.028 \\
-.025 \\
-.024\end{array}$ & $\begin{array}{l}{[.002]} \\
{[.002]}\end{array}$ & $\begin{array}{l}-.039 \\
-.039\end{array}$ & $\begin{array}{l}1.6 \\
1.7 \\
1.7 \\
1.7\end{array}$ & $\begin{array}{l}-.074 \\
-.086 \\
-.076 \\
-.064\end{array}$ & $\begin{array}{l}(.019) \\
(.019)\end{array}$ & $\begin{array}{l}-.111 \\
-.111\end{array}$ & $\begin{array}{l}1.5 \\
1.8 \\
1.9 \\
1.5\end{array}$ \\
\hline $\begin{array}{l}\text { Sules } \\
\text { Frainc }\end{array}$ & $\begin{array}{l}-.028 \\
-.032 \\
-.029 \\
-.025\end{array}$ & $\begin{array}{l}(.006) \\
(.006)\end{array}$ & $\begin{array}{l}(-.036) \\
(-.036)\end{array}$ & $\begin{array}{l}2.2 \\
2.6 \\
2.5 \\
2.1\end{array}$ & $\begin{array}{l}-.064 \\
-.081 \\
-.073 \\
-.057\end{array}$ & $\begin{array}{l}.028 \\
.028\end{array}$ & $\begin{array}{l}(-.084) \\
(-.084)\end{array}$ & $\begin{array}{l}1.7 \\
2.6 \\
1.6 \\
1.6\end{array}$ \\
\hline $\begin{array}{l}\text { British } \\
\text { Pound }\end{array}$ & $\begin{array}{l}-.018 \\
-.033 \\
-.035 \\
-.019\end{array}$ & $\begin{array}{l}.027 \\
.027\end{array}$ & $\begin{array}{l}{[.016]} \\
{[.016]}\end{array}$ & $\begin{array}{l}.55 \\
1.7 \\
1.9 \\
.59\end{array}$ & $\begin{array}{l}-.014 \\
-.027 \\
-.028 \\
-.015\end{array}$ & $\begin{array}{l}.023 \\
.023\end{array}$ & $\begin{array}{l}{[.016]} \\
{[.016]}\end{array}$ & $\begin{array}{r}.5 \\
1.5 \\
1.8 \\
.6\end{array}$ \\
\hline $\begin{array}{c}\text { Japanese } \\
\text { Yen }\end{array}$ & $\begin{array}{l}-.031 \\
-.020 \\
-.015 \\
-.026\end{array}$ & $\begin{array}{l}-.019 \\
-.019\end{array}$ & $\begin{array}{l}-.062 \\
-.062\end{array}$ & $\begin{array}{l}.79 \\
1.5 \\
2.1 \\
.62\end{array}$ & $\begin{array}{l}-.056 \\
-.050 \\
-.036 \\
-.052\end{array}$ & $\begin{array}{l}-.026 \\
-.026\end{array}$ & $\begin{array}{l}-.159 \\
-.159\end{array}$ & $\begin{array}{l}1.0 \\
1.3 \\
2.1 \\
0.9\end{array}$ \\
\hline
\end{tabular}

A coefficient in parentheses exceeds its standard error but is less than twice its standard error. A coefficient in square brackets is less than its standard error. Other coefficients are wore than twice their standard error. Constant terns are estivated but not shown shom. The $R^{2}$ of each equation excoeds 0.9 except for the first and fourth equations for the British pound. 
The next four rows relate to the behavior of the Morgan Guaranty Bank bilateral trade weighted index of the dollar's value. This index is a weighted average of the exchange rates between the dollar and 16 currencies, weighting the exchange rate by the volume of trade between that country and the United states. This differs from the Federal Reserve Bank's multilateral index which weights individual exchange rates on the basis of that country's share in world trade. The conceptual advantage of using world trade weights for each bilateral exchange rate is that the world trade weights reflect the fact that the United States competes against (say) German products not only in Germany but in other countries as well. As a practical matter, the primary effect of using the Morgan Guaranty index is to give substantially much more weight to Canada than in the multilateral index.

The coefficients for the bilateral index are somewhat smaller than the corresponding multilateral ones (about one-fifth smaller for the trends and about one-third smaller for the shift coefficient) but otherwise very similar in the story that they tell. The smaller size of the coefficients is due primarily to the fact that the Canadian dollar has actually depreciated relative to the U.S. dollar and this bilateral relationship is given substantially more weight in the Morgan Bank index than in the Federal Reserve's multilateral index. Note in particular that the estimated coefficient of Time2 is very small (less than one percent of the basic time trend) and less than its standard 
error.

The behavior of the German mark (DM) is particularly important because the DM is not only the principal European currency but also because, through the European Monetary System. the DM effectively governs the exchange rates of the other European currencies with the dollar. The estimated coefficients indicate that the dollar fell relative to the DM at the same rate of about 2.5 percent a month after the G-5 meeting as it had before. The coefficient of the second time trend is positive and less than its standard error. The evidence also indicates that the drop in the dollar immediately after the G-5 meeting has largely persisted. The dollar-mark relationship is thus very similar to the pattern observed for the multilateral trade weighted value of the dollar. ${ }^{\circ}$

The linear specification of the dollar-DM relation provides essentially the same picture but with a somewhat stronger indication that the dollar's rate of decline has actually slowed since the G-5 meeting. The point estimates of the coefficients indicate that the dollar fell at a rate of 7.6 pfennigs per month before the G-5 meeting but only 5.7 pfennings per month after the G-5 meeting. The positive secondary time trend of 1.9 pfennigs per month was more than enough to outweigh the 11.1 pfennig

- Excluding the month of september from the sample reduces the size and statistical significance of the shift term (to 3.2 percent with a standard error of 1.9 percent) but otherwise leaves the picture of the dollar-mark relationship essentially unchanged. Results for the sample without september 1985 are presented as appendix table A-1. 
decline at the time of G-5 meeting before the summer of 1986 . The relatively large standard error of the secondary time trend requires caution in this interpretation. The alternative view that the dollar has declined at a constant rate of 6.4 pfennings per month, with a one time additional drop of 11.1 pfennigs at the time of the G-5 meeting, cannot be rejected at standard levels of significance.

Although the Swiss franc is not part of the European Monetary System, the Swiss have pursued a policy of pegging the Swiss franc to the German mark. The success of this policy is apparent in the general similarity of the coefficients for the Swiss franc and the German mark. The franc declined at a rate of 2.5 percent before and after the G-5 meeting with a one-time 3.6 percent decline in the dollar-franc ratio after the G-5 meeting occurred. The point estimates are thus almost identical to those of the German mark. However, the larger standard error of the shift coefficient in the dollar-franc relation suggests that there may not have been any persistent decline in the level of the dollar relative to the Swiss franc after the G-5 meeting. Moreover, the linear specification for the dollar-franc relation implies that the dollar decline slowed significantly after the G5 meeting (from 8.1 centimes per month before the G-5 to 5.3 centimes per month after the G-5 meeting).?

\footnotetext{
When the observation for september 1985 is omitted the estimated linear relation is essentially unchanged while the estimates with the logarithmic specification becomes similar to the linear results; i.e.. the second time trend is significantly positive and equal to about one-third of the basic time trend.
} 
The dollar's ratio to the British pound behaved very differently than the dollar's ratio to the other G-5 currencies. For the period as a whole, the dollar declined relative to the pound at an average rate of only 1.8 percent a month, substantially less than the 2.7 percent rate against the mark and the 3.1 percent rate against the yen. Moreover, the time trend relation is statistically weak with a corrected $R^{2}$ of only 0.83 and a Durbin-Watson statistic of 0.55 that indicates a fundamental misspecification in the log-linear time trend. Introducing the second time trend not only improves the overall fit of the equation (raising the corrected $R^{2}$ to 0.95 ) but also eliminates the serious serial correlation of the residuals (with the Durbin-watson statistic rising to 1.7 ). The second post-G5 time trend is positive and about as large in absolute size as the basic negative trend. These estimates thus imply that the dollar fell relative to the pound at a rate of 3.3 percent a month until the G-5 meeting but only declined at a rate of 0.6 percent a month after the meeting. A similar pattern emerges in the linear specification. The dollar's rate of decline relative to the pound was substantially less after the G-5 meeting than it had been before.

The final currency to be considered is the Japanese yen." In contrast to the experience relative to the other G-5

- Although the French franc is also one of the G-5 currencies. I have not presented results for the French franc because its behavior so closely parallels that of the German mark to which it is tied through the EMS. 
currencies, the dollar did decline more rapidly relative to the yen after the G-5 meeting than before. The estimates shown in table 1 indicate that the dollar-yen ratio fell at a rate of 1.5 percent per month before the G-5 meeting, and 3.4 percent after the meeting. In addition, the dollar-yen ratio shifted down by a persistent 6.2 percent at the time of the meeting. The linear specification presents a similar pattern. This picture is unchanged by omitting the observation for september.

It would be wrong, however, to interpret this rise in the yen as evidence of the efficacy of sterilized intervention. At the time of the G-5 meeting the Japanese announced that they would change their domestic monetary policy in order to increase the value of the yen.' Short-term yen interest rates in Japan were raised sharply to make yen investments more attractive, the 3-month Euroyen rate rising within six weeks of the G-5 meeting from the 6.25 to 6.50 range where it had been for the past two years to more than 8.0 percent by mid-November. The dollar declined by approximately 15 percent against the yen during this six week period, a decline equal to nearly two-thirds of the dollar's accelerated fall against the yen between september and June. The question that remains to be settled by future research is whether nonsterilized intervention during this period raised the yen by any more than would have been expected from the tightening of monetary policy alone.

\footnotetext{
The Japanese statement promised that Japan would follow a "flexible management of monetary policy with due attention to the yen rate."
} 
Although nominal yen interest rates have declined since late 1985, real interest rates in Japan have been extremely high as Japanese producer prices fell by an unprecedented 10 percent in the 12 months through June 1986. The value of the yen relative to other currencies was also raised during the first half of 1986 by the unexpected and sharp fall in the price of oil. Since the Japanese produce no oil domestically. the fall in the price of oil represented a major unexpected improvement in Japan's future trade balance. The decline in the cost of oil imports required a rise in the yen in order to shrink Japan's non-oil trade surplus to maintain the initial level of the capital outflow.

It will take additional econometric research to see whether the unusually rapid rise in the yen since september 1985 is fully explained by the such fundamental factors as the shift in Japanese monetary policy, the decline in the price of oil, and the surprising strength of the Japanese trade balance. Although the possibility that intervention per se accelerated the yen's rise cannot be ruled out until that reserach is done, the current evidence can hardly be said to provide a powerful case for the efflcacy of sterilized intervention. This is particularly true since the Japanese were subsequently unsuccessful when they intervened in an attempt to stop the yen's further appreciation when it reached an exchange rate of 180 yen to the dollar. 


\section{An Analysis of Weekly Exchange Rate Movements}

The relatively short period since the dollar began to decline provides only 16 monthly observations on each exchange rate. A shift to weekly observations permits a more than fourfold increase in the number of observations, although the increase in actual information is obviously much less.

Table 2 presents the estimated coefficients based on weekly observations from the first full week of March 1985 through the last week of June 1986. The two time trend variables are now measured in weeks, implying that the scale of the trend coefficients should be smaller than the corresponding monthly coefficients by a factor of approximately 4.3 .

Ordinary least squares estimates with the weekly data generally had very low Durbin-Watson statistics (below one), implying serious autocorrelation of the disturbances. In the current context, with truly exogenous regressors, such autocorrelation results in inefficient but unbiased parameter estimates with biased standard errors. The coefficients presented in table 2 are therefore estimated with a first-order autocorrelation correction. The simultaneously estimated autocorrelation parameter is also shown (in the column marked rho). The Durbin-Watson statistics of these transformed estimates are generally between 1.5 and 2.0 . A comparison of the transformed and oLs estimates actually shows very little difference.

The estimates based on weekly data presented in Table 2 
Table 2

Analysis of Meekly Dollar Exchange Rate Movenents March 1985 through June 1986

\begin{tabular}{|c|c|c|c|c|c|c|c|c|c|c|}
\hline $\begin{array}{l}\text { Currency or } \\
\text { Index }\end{array}$ & & $\begin{array}{l}\text { Logart } \\
\text { soectifi }\end{array}$ & $\begin{array}{l}\text { thic } \\
\text { ation }\end{array}$ & & & & $\begin{array}{r}L 1 \\
\text { spectf }\end{array}$ & near & & \\
\hline & Ine & Ifre? & Shift & tho & DS & Tre & the? & Shift & Bho & DS \\
\hline $\begin{array}{l}\text { Multilateral } \\
\text { Trade neighted } \\
\text { Inden }\end{array}$ & $\begin{array}{l}-.0053 \\
-.0035 \\
-.0049 \\
-.0043\end{array}$ & $\begin{array}{l}-.0015 \\
{[.0009]}\end{array}$ & $\begin{array}{l}-.074 \\
-.050\end{array}$ & $\begin{array}{l}.74 \\
.82 \\
.76 \\
.77\end{array}$ & $\begin{array}{l}1.3 \\
1.4 \\
1.4 \\
1.4\end{array}$ & $\begin{array}{l}-.0065 \\
-.0029 \\
-.0048 \\
-.0050\end{array}$ & $\begin{array}{l}-.0025 \\
{[-.0003]}\end{array}$ & $\begin{array}{l}{[-.065]} \\
-.073\end{array}$ & $\begin{array}{l}.76 \\
.77 \\
.77 \\
.77\end{array}$ & $\begin{array}{l}1.3 \\
1.3 \\
1.3 \\
1.3\end{array}$ \\
\hline $\begin{array}{l}\text { Morgan Bank } \\
\text { Bilateral } \\
\text { Index }\end{array}$ & $\begin{array}{l}-.0040 \\
-.0021 \\
-.0030 \\
-.0030\end{array}$ & $\begin{array}{l}-.0016 \\
{[-.0008]}\end{array}$ & $\begin{array}{l}-.049 \\
-.051\end{array}$ & $\begin{array}{l}.69 \\
.84 \\
.81 \\
.81\end{array}$ & $\begin{array}{l}1.4 \\
1.4 \\
1.4 \\
1.4\end{array}$ & $\begin{array}{l}-.0048 \\
-.0021 \\
-.0040 \\
-.0036\end{array}$ & $\begin{array}{l}-.0021 \\
{[-.0006]}\end{array}$ & $\begin{array}{l}-.083 \\
-.065\end{array}$ & $\begin{array}{l}.71 \\
.88 \\
.82 \\
.82\end{array}$ & $\begin{array}{l}1.4 \\
1.4 \\
1.4 \\
1.4\end{array}$ \\
\hline $\begin{array}{l}\text { Cernan } \\
\text { art } \\
\text {. }\end{array}$ & $\begin{array}{l}-.0063 \\
-.0045 \\
-.0056 \\
-.0053\end{array}$ & $\begin{array}{l}-.0016 \\
{[.0005]}\end{array}$ & $\begin{array}{l}-.068 \\
-.054\end{array}$ & $\begin{array}{l}.66 \\
.71 \\
.67 \\
.67\end{array}$ & $\begin{array}{l}1.7 \\
1.8 \\
1.8 \\
1.8\end{array}$ & $\begin{array}{l}-.017 \\
-.012 \\
-.017 \\
-.014\end{array}$ & $\begin{array}{l}-.005 \\
(.005)\end{array}$ & $\begin{array}{l}-.298 \\
-.162\end{array}$ & $\begin{array}{l}.71 \\
.78 \\
.67 \\
.71\end{array}$ & $\begin{array}{l}1.7 \\
1.9 \\
1.8 \\
1.8\end{array}$ \\
\hline $\begin{array}{l}\text { Sules } \\
\text { franc }\end{array}$ & $\begin{array}{l}-.0065 \\
-.0040 \\
-.0067 \\
-.0035\end{array}$ & $\begin{array}{l}-.0013 \\
(.0017)\end{array}$ & $\begin{array}{l}-.097 \\
-.051\end{array}$ & $\begin{array}{l}.65 \\
.72 \\
.62 \\
.67\end{array}$ & $\begin{array}{l}1.7 \\
1.8 \\
1.8 \\
1.8\end{array}$ & $\begin{array}{l}-.015 \\
-.011 \\
-.017 \\
-.012\end{array}$ & $\begin{array}{r}-.003 \\
.007\end{array}$ & $\begin{array}{l}-.324 \\
-.131\end{array}$ & $\begin{array}{l}.73 \\
.81 \\
.62 \\
.74\end{array}$ & $\begin{array}{l}1.8 \\
1.9 \\
1.8 \\
1.9\end{array}$ \\
\hline $\begin{array}{l}\text { British } \\
\text { pound }\end{array}$ & $\begin{array}{l}.0042 \\
.0024 \\
.0068 \\
.0032\end{array}$ & $\begin{array}{l}.0017 \\
-.0061\end{array}$ & $\begin{array}{l}.219 \\
.060\end{array}$ & $\begin{array}{l}.85 \\
.91 \\
.75 \\
.88\end{array}$ & $\begin{array}{l}2.0 \\
2.0 \\
1.9 \\
2.0\end{array}$ & $\begin{array}{l}.005 \\
.003 \\
.008 \\
.004\end{array}$ & $\begin{array}{l}.002 \\
-.007\end{array}$ & $\begin{array}{l}.259 \\
.081\end{array}$ & $\begin{array}{l}.81 \\
.89 \\
.72 \\
.86\end{array}$ & $\begin{array}{l}2.0 \\
2.1 \\
1.9 \\
2.0\end{array}$ \\
\hline $\begin{array}{l}\text { Japaneseo } \\
\text { yea }\end{array}$ & $\begin{array}{l}-.0070 \\
-.0017 \\
-.0034 \\
-.0062\end{array}$ & $\begin{array}{l}-.0020 \\
-.0044\end{array}$ & $\begin{array}{l}.077 \\
-.049\end{array}$ & $\begin{array}{l}.85 \\
.73 \\
.61 \\
.84\end{array}$ & $\begin{array}{l}1.7 \\
2.0 \\
1.9 \\
1.7\end{array}$ & $\begin{array}{l}-.015 \\
-.009 \\
-.009 \\
-.013\end{array}$ & $\begin{array}{l}-.005 \\
-.006\end{array}$ & $\begin{array}{l}{[.056]} \\
-.118\end{array}$ & $\begin{array}{l}.82 \\
.63 \\
.62 \\
.78\end{array}$ & $\begin{array}{l}1.6 \\
1.9 \\
1.9 \\
2.0\end{array}$ \\
\hline
\end{tabular}

All equations are estivated with a first-order autocorrelation correction. The autcoorrelation coefficient of the lagged residual is shown as Rho.

a coefficient in parentheses standard error. I coefficient in equare bracteats is less than its standard error. Other coefficients are wre than twice their standard errors. Constant terns are ostinated but not shown. The $R^{2}$ of exch equation excoeds 0.9 . 
confirm the conclusions based on the monthly estimates presented in Table 1. With the exception of the relation to the Japanese yen. the evidence indicates that the dollar shifted down by about 5 percent after the G-5 meeting but that there has not been an accelerated rate of decline since then.

Consider, for example, the multilateral trade weighted index. The first entry in the table shows that this declined at a rate of 0.53 percent per week, just in line with the 2.3 percnt per month decline shown in Table 1 . When a second time trend is introduced, the parameter estimates imply a 0.35 percent weekly decline before the G-5 meeting and a 0.50 percent weekly decline after the G-5 meeting. But this is a spurious result, as the next entry in the table indicates. When a shift term is introduced, it is statistically significant while the second time trend becomes positive. very small and less than half of its standard error. The final entry for the multilateral trade weighted index shows that the index declined at 0.43 percent per week over the entire period but with a 5.0 percent downward shift immediately after the G-5 meeting.

The result is essentially the same for the bilateral Morgan Guaranty index, the German mark and the Swiss franc. The results for the British pound are quite erratic, suggesting more of a positive trend and upward shift in the dollar's relative value than that implied by the monthly data. Only for the yen is there clear evidence of a greater decline in the post-G5 period than before, just as with the monthly data. 
The linear specifications present a similar picture: a moderate downward shift in the dollar after the G-5 meeting but no evidence of a more rapid decline in the post-G5 period than before except for the yen.

\section{Concluding Comment}

The September 1985 decision of the G-5 countries to pursue coordinated intervention has been widely credited with the subsequent sharp decline of the dollar relative to other major currencies. On the surface, the dollar's decline appears as evidence that coordinated intervention can be an effective instrument of economic policy, contrary to most of the previous economic analysis of this issue.

The evidence in the present paper shows that such a conclusion is unwarranted. The dollar's decline in the nine months after the G-5 agreement was generally no faster than it had been since the beginning of its decline in the spring of 1985. The only indication of discontinuity in the overall behavior of the dollar was a drop of about 4 percent that occurred immediately after the G-5 meeting and that has largely persisted.

Although this evidence cannot be taken as a conclusive indication that coordinated intervention had no effect on the exchange rate, it does show the inappropriateness of interpreting the dollar's decline after september 1985 as evidence that coordinated intervention was effective. 
The special case of the Japanese yen is more ambiguous. Unlike all of the other G-5 currencies, the yen did appreciate more rapidy after the $G-5$ meeting than it did before. But the Japanese government was also unique in making a major shift in monetary policy immediately after the G-5 meeting to strengthen the yen and the yen was also the major currency that could be expected to appreciate most as a result of the massive and unexpected decline of the price of oil in the first half of 1986 . Only careful econometric work can hope to resolve whether the policy of coordinated intervention had an effect on the course of the dollar after the G-5 agreement. The analysis of the present paper shows that until such evidence is produced. it would be wrong to infer that intervention as such played any part in causing the dollar's rapid decline since september 1985.

Cambridge. Mass.

August 1986 


\section{Appendix Table A-1}

Analysis of Monthly Dollar Euchange Rate Measurewents

Karch 1985 through June 1986 excluding Sept 1985

$$
\begin{aligned}
& \text { Currency or } \\
& \text { Indey }
\end{aligned}
$$

Logarithuic

Specification

\section{Linear \\ Specification}

\section{Ine Tine? Shift Dus Iine Iire? shift Dus}

$\begin{array}{lllllllll}\text { Multilateral } & -.023 & & 1.4 & -.030 & & 1.1 \\ \text { Trade Neighted } & -.028 & .0074 & & 1.8 & -.040 & .016 & & 2.0 \\ \text { Index } & -.025(.0062) & {[-.015]} & 2.0 & -.037 & .014 & {[-.019]} & 2.1 \\ & -.021 & & (-.024) & 1.7 & -.027 & & (-.041) & 1.4\end{array}$

\begin{tabular}{|c|c|c|c|c|c|c|c|}
\hline $\begin{array}{l}\text { German } \\
\text { eart }\end{array}$ & $\begin{array}{l}-.027 \\
-.030 \\
-.027 \\
-.025\end{array}$ & $\begin{array}{l}(.005) \\
{[.004]}\end{array}$ & $\begin{array}{l}(-.027) \\
(-.032)\end{array}$ & $\begin{array}{l}1.3 \\
1.4 \\
1.6 \\
1.5\end{array}$ & $\begin{array}{l}-.074 \\
-.092 \\
-.083 \\
-.065\end{array}$ & $\begin{array}{l}.030 \\
.027\end{array}$ & $\begin{array}{l}(-.073) \\
(-.103)\end{array}$ \\
\hline $\begin{array}{l}\text { Sutsos } \\
\text { franc }\end{array}$ & $\begin{array}{l}-.028 \\
-.035 \\
-.033 \\
-.026\end{array}$ & $\begin{array}{l}.011 \\
.010\end{array}$ & $\begin{array}{l}\{-.016\} \\
(-.028)\end{array}$ & $\begin{array}{l}1.4 \\
2.2 \\
2.3 \\
1.6\end{array}$ & $\begin{array}{l}-.064 \\
-.087 \\
-.084 \\
-.057\end{array}$ & $\begin{array}{l}.040 \\
.039\end{array}$ & $\begin{array}{l}{[-.032]} \\
(-.076)\end{array}$ \\
\hline
\end{tabular}

$\begin{array}{lllllllll}\text { Morgan Bank } & -.017 & & & 1.9 & -.021 & & 1.6 \\ \text { Bilateral } & -.020 & (.003) & & 2.1 & -.025 & .007 & & 2.2 \\ \text { Indes } & -.018 & {[.003]} & {[-.009]} & 2.2 & -.024 & (.006) & {[-.012]} & 2.3 \\ & -.016 & & (-.013) & 2.1 & -.019 & & (-.021) & 1.9\end{array}$

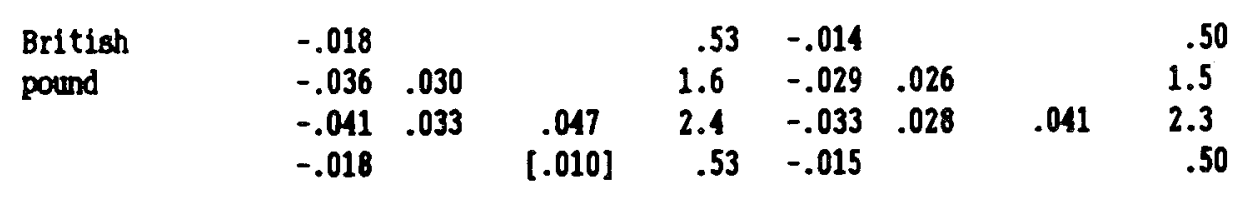

$\begin{array}{lcccccccc}\text { Japanese } & -.031 & & & .74 & -6.55 & & & .81 \\ \text { yea } & -.022 & -.015 & & 1.2 & -5.52 & (-1.77) & & .93 \\ & -.015 & -.018 & -.059 & 2.2 & -3.77 & -2.50 & -15.2 & 2.2 \\ & -.028 & & (.039) & .79 & -5.48 & & -12.3 & 1.1\end{array}$

A coefficient in parentheses exceeds its standard error but is less than twice its standard error. A coefficient in square brackets is less than its standard error. Other coefficients are wre than twice their standard error. Constant terns are estinated but not shown. The $R^{2}$ of each equation erceeds 0.9 except for the first and fourth equations for the British pound. 


\section{REFERENCES}

Feldstein. M. (1986a). "U.S. Budget Deficits and European Economies: Resolving the Political Economy Puzzle," American Economic Review. May.

Feldstein. M. (1986b). "The Budget Deficit and the Dollar." NBER Macroeconomic Annual, forthcoming.

Feldste1n. M.. and P. Bacchetta (1986), "U.S. Budget Def1c1ts and European Unemployment: The German Experience." forthcoming. Obstfeldt. Maurice (1985). "Floating Exchange Rates: Experience and Prospects." Brookings Papers on Economic Activity. $1985: 2$. pp. $369-450$.

Cooper. Richard (1985). "Comment on Obstfeldt." In Brookings Papers on Economic Act1v1ty. 1985:2. pp. 451-56. McKinnon, R. (1984), An International standard for Monetary Stabilization. Policy Analyses in International Economics No. 8. Institute for International Economics. Bergsten. C. Fred (1986). "Overview." In R. Roosa et. al.. The U.S. Dollar - Recent Developments, Outlook and Pollay Optlons, Ransas C1ty: Eederal Reserve Bank of Kansas C1ty. Meese, R. and $K$. Rogoff (1985). "Was 1t Real? The Exchange RateInterest Differential Relation, 1973-1984." NBER Working Paper No. 1732 . 